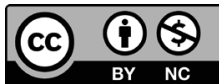

\title{
GENDER POLITICAL VIOLENCE AND THE UNFULFILLED PROMISE OF SUBSTANTIAL DEMOCRACY: A LOOK AT BRAZIL AND COLOMBIA
}

VIOLÊNCIA POLÍTICA DE GÊNERO E A PROMESSA INCUMPRIDA DE DEMORACIA SUBSTANCIAL: UM OLHAR SOBRE O BRASIL E A COLÔMBIA

\author{
Edilene Lôbo \\ David Mendieta \\ Daiane Moura de Aguiar
}

\begin{abstract}
This article problematizes gender political violence, exposing the unfulfilled promise of the constitutional State, broken by the perpetuation of patriarchal structures, reinforced by racism. This is a reflection on Brazil and Colombia, similar cultural models in Latin America, examining the legislation that reserves quotas for the registration of female applications and the challenge imposed on the justice system in combating fraud of these rules. The reach and effectiveness of affirmative action, the proof of fraud and the consequences of its finding, are the themes that arise to the debate, filtered by the paradigm of a democratic state that obeys the rule of law.
\end{abstract}

Keywords: Gender democracy. Reach and effectiveness. Political Violence. Racial quotas fraud. Electoral justice system. 


\section{RESUMO}

Este artigo problematiza a violência política de gênero, expondo a promessa incumprida do Estado constitucional, alquebrada pela perpetuação das estruturas patriarcais, reforçadas pelo racismo. Trata-se de reflexão sobre o Brasil e a Colômbia, modelos culturais similares na América Latina, examinando a legislação que reserva cotas para o registro de candidaturas femininas e o desafio imposto ao sistema de justiça no combate à fraude dessas regras. 0 alcance e a efetivação da ação afirmativa, a prova da fraude e as consequências da sua constatação, são os temas que se colocam ao debate, filtrados pelo paradigma de Estado Democrático de Direito.

Palavras-chave: Democracia de gênero. Alcance e efetivação. Violência política. Fraude às cotas. Sistema de justiça eleitoral.

\section{INTRODUCTION}

Secular violence against women, aggravated during the pandemic of COVID-19 with the isolation of the victim in the same space as the aggressor, associated with the demobilization of security equipment and the justice system, exposed even more crudely the slaughter of abuse. ${ }^{1,2}$

The structural problem of the silencing and extermination of women in the private environment, in alarming numbers in Latin America ${ }^{3}$, extends to the realm of politics, despite the growing and increasingly incisive debate about the importance of public policies aimed at gender equality.

At the core of world constitutionalism, gender democracy means the inclusion of women, without reductions, in the decision-making process, for the legitimacy of the exercise of power and the implementation of fundamental rights. However, it is still an unfulfilled promise, challenging the rule of law, desired pattern and always distant, as if it were enough to have it as a picture on the memory wall.

It is plain to see that in the legal realm, all Brazilian constitutions, from the Imperial of 1824 to the one that succeeded the military dictatorship, from 1988, describe equality between people as a fundamental political right. Similarly, the Colombian constitutions are based, with emphasis on the current one, from 1991. 
This formal evidence, however, finds no proper way out in the world of life, is not real. Based on this, legal and judicial measures are necessary establishing quotas for the registration of women, the partition of financial resources and time on the radio and TV advertising, yet without contemplating parity, as if it was enough to reserve a niche, away from equality as a value.

As recent figures show, in the elections of these two countries, the political ostracism of women, especially black women, remains. And so it will be as long as there is no definitive rupture with the patriarchal model and the indifference that naturalized racism.

Dealing with this ambivalent relationship between the facticity denying the inclusion and validity of legal rules, this article begins with the quota model in both countries, describing the financing of the electoral campaign of women and the reserve of time on radio and television advertising, and the numbers found after the recent elections.

Secondly, it examines the judicial control of political violence by the respective justice systems, concluding by the need to detail criminal law to typify gender political violence, foresee the structuring types of conduct and to establish the effects of the declaration of fraud, so that the teratology revealed in recent decisions of the Brazilian electoral court is not disclosed that, to condone the illicit, revokes all the mandates conferred, including well-voted and recognized women in their communities, reaching the principle of non-transcendence of the penalty and emptying affirmative action.

In the guise of final considerations, through the international documents conducting the subject, the need for a model for the southern part of Latin America is considered, who suffers from the same problems and needs, more than ever, to expand recent Chilean practice, which for the first time will write its Constitution on an equal footing, drawing attention to a new constitutional model from the perspective of gender. The defense, therefore, is of a new constitutionalism, this time, feminist. 


\section{THE LEGAL QUOTA MODEL}

In Brazil, elections to the Federal Chamber, the Legislative Assemblies of States and Municipalities, parties can lead to registration of up to $150 \%$ of the seats to be filled. The exception is for States where the number of seats, for the Federal Chamber, is not more than 12, and in Municipalities with up to 100,000 voters, the possibility goes to $200 \%$.

It is provided in Law No. 9,504 of 1997, amended several times throughout its existence, which set a minimum record of $30 \%$ of women on the lists of political parties, following a trail left since 1995, by Law No. 9,100 . The choice takes place at the party convention scheduled every election year, without which no candidacy has a guaranteed record.

In Colombia, Law No. 581 of 2000 and Law No. 1,475 of 2011, establishes, respectively, that $30 \%$ of the high administrative positions of public authorities must be held by women and that, in the lists of the parties, where 5 or more seats are disputed for popular election corporations, the equal percentage should be guaranteed for the minority gender.

Some sectors approve the quota laws, both in Brazil and Colombia, but over time, it is observed that they end up creating invisible barriers, which generalizes the belief that $30 \%$ is the maximum, when at most, a goal to be observed, without greater criteria of objectivity.

It is enough to see that in the Colombian elections for the Congress of the Republic, in the Governments of the Provinces and in the Prefectures, in 2018, the percentage of women elected was minimal, as demonstrated by the following chart ${ }^{4}$ :

\begin{tabular}{|c|c|c|c|}
\hline & $\begin{array}{c}\text { Congress of } \\
\text { the Republic }\end{array}$ & $\begin{array}{c}\text { Governments of } \\
\text { the Provinces }\end{array}$ & Prefectures \\
\hline Total seats & 276 & 32 & 1.103 \\
\hline $\begin{array}{c}\text { Number of } \\
\text { women elected }\end{array}$ & 55 & 2 & 132 \\
\hline Percentage & $19.93 \%$ & $6.25 \%$ & $12.2 \%$ \\
\hline
\end{tabular}


Although it cannot be denied that there have been advances with quota laws, they are very little for a country where $51.2 \%$ of the inhabitants are women.

In the Brazilian elections of 2020 , boasting negligible growth rates, the result was no different.

In total, 370,000 males applications were registered against 187,000 females, with 1 woman for every 10 men running for the leadership of the municipal executive and 34 women in every 100 for the city council of parliamentarians.

The percentage of female mayors and vices, comparing 2016 with 2020 , ranged from $11.6 \%$ and $14.5 \%$ to $12 \%$ and $16.4 \%$, respectively.

A single capital will be administered by a woman in Brazil, from 2021: Palmas, in the State of Tocantins.

The percentage of councilwomen went from $13.4 \%$ to $15.7 \%$, with 9,196 elected ${ }^{5}$.

In proportional numbers very close to those of Colombia, women in Brazil are $51.8 \%$ of the population and $52 \%$ of the electorate, but patriarchy imposed on them $30 \%$ as the maximum to aspire, without any attention to substantial democracy, creating the crystal ceiling that is difficult to overcome (COELHO, 2020).

When it comes to the election of black women, although with some growth in the capitals of Brazil, the results are even more impressive, in the perverse intertwining between racism and structural sexism, which naturalized the exclusion of this immense majority of the population.

The 2016 Brazilian election resulted in $5 \%$ of black councilors, with 67,000 candidates, an increase in $1.3 \%$ in 2020 , with 90,000 competing $^{6}$. These figures show that black women have advanced in the occupation of public spaces of power, but political violence of gender and race has risen in exponential proportion. The Marielle Franco Institute revealed in a recent survey that $78 \%$ of black women, candidates in the 2020 elections, suffered virtual violence ${ }^{7}$.

Violence against the black population, prominently in women, is measured by the colors of those who are in prison, of those who are persecuted by the police, of whom they are exterminated by physical violence, who is marked by racial discrimination that overlaps with white 
people holding the legal authority, political power, the realm of wealth, to blackness, subalternate and still enslaved today, now under the shackles of poverty, political and social exclusion, now in the bars of the clogged chains of young lives erased forever.

\section{PUBLIC FUNDING OF CAMPAIGNS}

Since corporate donations to the campaigns ${ }^{8}$ were banned, in Brazil, the Special Campaign Finance Fund (SCFF), in 2017, by Law No. 13,487, consisting of budget appropriations of the Federal Government, first experienced in the 2018 elections, which, as determined by the Supreme Court in the judgment of the Direct Action of Unconstitutionality 5617, $30 \%$ at least, are reserved for women. The same understanding extended to another public resource, created for financial assistance to political parties by the Constitution, outlined Law No. 9,096 of 1995, which can also be applied in election campaigns.

Corroborating the financial quota, the Superior Electoral Court, in Consultation No. 0600252-18, also established the distribution of advertising time on radio and TV, in the same minimum percentages.

Thus, in Brazil, although donations from individuals to election campaigns are still admitted, the funding is mostly public, but it is not distributed equally between genders. On the contrary, women are the majority of the electorate but receive almost half of the money allocated for men.

Recent novelty, but of applicability still without mechanisms of execution and control, for the 2020 campaigns, seeking some inflection in the discouraging picture, recognizing the "unconstitutional state of accounts" with the structural racism prevailing in the Brazilian political process, the Decision of the Supreme Court in ADPF $738^{9}$, in September, set financial quotas for the candidacies of black people, imposing an obligation on political parties to measure equity between gender and race, when distributing the money.

In Colombia, campaign financing is mixed, very close to the Brazilian model, with the express non-admission of private resources that have 
undemocratic or attentive purposes to public order, as established in Article 109 of the Constitution.

The regulation of the matter is in charge of Law No. 130, of March 1994, which provides for public resources for campaigns, the possibility of using radio and TV for advertising, but without provision of quotas for women and/or effective control mechanisms.

\section{THE ELECTORAL JUSTICE SYSTEM}

The organization of the Colombian electoral justice system has two instances. The National Electoral Council is the highest authority, whose mission is to regulate and monitor compliance with the provisions of the Constitution and the Law on the subject, as well as to apply and issue regulations. It is also the council's function to control the lists containing the female quotas, having the authority to void them if they do not comply with the legal minimums.

The other body is the National Register of the Civil State, responsible for organizing the elections, investigating and proclaiming the results.

In this country, the Administrative Department of the Civil Service (ADCS) must submit an annual report on the number of positions held by women in each public administration body (Article 12 of Law No. 581 of 2000). And the authorities charged with keeping compliance with this law are the Attorney General of the Nation and the Defender of the People (Article 16 of Law No. 581 of 2000), that belong to the staff of the Public Prosecutor's Office, which is an autonomous and independent body.

In Brazil, there is a long specialized judicial structure, as are the articles 118 to 121 of the Constitution, with the Superior Electoral Court as the governing body, based in the Capital of the country, composed of seven judges out of three from the Supreme Court, two from the Superior Court of Justice and two jurists appointed by the President of the Republic. At the moment, this Court, which has already been presided over by women, does not have them in its structure as titular judges.

In the State Capitals, there are the Regional Electoral Courts, with seven judges, among which two judges of the State Court of Justice, 
two state judges, a federal judge, and two jurists appointed by the President of the Republic.

Besides, there are the state judges who are responsible for the Electoral Zones and, during the elections, the Electoral Boards, responsible for the calculation of the vote and proclamation of the results.

Based on the Superior Electoral Court of Brazil analysis, of the recent elections, the recognition that there was an "increase in physical or moral attacks on women candidates", as said its President, Minister Luís Roberto Barroso $^{10}$ (Own translation).

Exemplifying these moral attacks, the Brazilian press highlighted the virulence of the campaign in social networks against two women, in geographical extremes of Brazil, both young and engaged in the political struggle, to demonstrate the territorial extent of the evil.

Marilia Arraes, with the stigma of anti-Christian and arrogant, because she showed more experience and is an activist of identity agendas, competing in Recife, in the State of Pernambuco, in the northeast of Brazil, in which the murder of women only loses to São Paulo, the most populous state of the Federation ${ }^{11}$.

Manuela D'Ávila, in Porto Alegre, Rio Grande do Sul, in the southernmost end of the country, is constantly attacked through fake news and swearing, for being a leftist woman, in the same strategy of political annihilation ${ }^{12}$.

All this violence is intended to discredit women's discourse, to eliminate possibilities of those who dare to present themselves to the dispute and threaten patriarchal power concentrated on white men, at the top of the legal-political-social structure.

Besides this moral persecution, in addition to the threats of physical extermination, there is another kind of political violence, equally deleterious and almost invisible, which is involved in the fraud of the registration of women and the refusal of public resources in equal parts for women's campaigns. 


\section{TREATMENT OF GENDER FRAUD BY THE BRAZILIAN JUSTICE SYSTEM}

Although there is no legislation typifying gender political violence with the clear description of its verbs, effects of its declaration and specific penalties, in Brazil, there are several draft bills in course, highlighting, at least, four more recent ones.

The first, Draft Bill No. 349/2015, of February 11, 2015, more than five years in progress, is authored by Congresswoman Rosângela Gomes, conceptualizing political-electoral violence as physical, psychological or sexual aggression against women, elected or even a candidate, to prevent, restrict or hindering access to political office, or even inducing her to make decisions contrary to her will.

This bill describes the acts capable of causing censored violence, providing for amendment of the Electoral Code to advocate illegal advertising that disparages the condition of women and stimulate discrimination of sex or race. In addition to regulating debates between proportional applications, to ensure the minimum participation of women in such activities.

The second Draft Bill, No. 4963/2020, of October 20, 2020, authored by Congresswoman Margarete Coelho, signed by other co-authored Congresswomen, considers political violence any action, conduct, or omission of physical, sexual, psychological, moral, economic, or symbolic violence, which poses a threat to democracy by causing harm or suffering to women to restrict, prevent or hinder the exercise of their political rights.

The third Proposed Bill, No. 5114/2020, of November 6, 2020, authored by Congresswoman Rejane Dias, defines political violence as any and all activities that restrict, disparage or impede women's political rights. It also provides for the crime of threat, embarrassment, dissemination of fake news, restriction or interruption of speech use, providing for detention penalty of three months to three years, plus fine, depending on the offensive potential of aggression.

The fourth and last Law Project, No. 5295/2020, of November 27, 2020, authored by Congresswoman Taliria Petrone, differentiates political harassment from political violence, fixing prohibition and punishment 
for any form of gender discrimination, specially racial, religious and age, particularly those carried out through social networks on the internet.

Addressing parity, this bill highlights the goal of guaranteeing women the full exercise of political rights, with conditions and opportunity, including the distribution of financial resources in an equitable way, applying parity and alternation in political representation in all organs and institutions.

It is strategic to gather and approve these projects, by all means.

However, they lack explicit mention of fraud in the registration of candidacies, declining the legal consequences of declaring such unlawful acts as the result of the claims.

For now, there are no clear prescriptions and punishments for parties, leaders, and candidacies that practice or allow the practice of this type of violence. This absence has had deleterious effects on women's political participation, when the Brazilian justice system is active, for the control of quota policy.

\section{PRECEDENTS OF BRAZILIAN ELECTORAL JUSTICE}

For the first time in 2015, inaugurating a new wave of women's political rights (LÔBO, 2018), twenty years after the first law dealing with the issue in Brazil, after the democratic reopening with the 1988 Constitution, judging Special Electoral Appeal No. 1-49, the Superior Electoral Court has recognized that the concept of this fraud is open and encompasses "all situations in which the normality of the elections and the legitimacy of the elective mandate are affected by fraudulent actions" (BRASIL, 2015), and can be syndicated through the Action of Impugnation of Elective Mandate, provided for directly in $\S 10$ of Article 14 of the Constitution.

The following year, municipal elections, with the trial of Special Electoral Appeal No. 24,342, the Superior Electoral Court again defined the possibility of verifying fraud in the gender account "through the electoral judicial investigation action" (BRASIL, 2016), to ascertain "if the political party effectively respected the normality of the elections 
provided in the legal system - both at the time of registration and in the course of election campaigns" (BRASIL, 2016) - "or if there is the launch of applications just to fill, in, fraud to the law, the minimum number of vacancies provided for each gender, without the effective development of applications" (BRASIL, 2016).

In these two opportunities, it was only dealt with procedural possibilities for the handling of the relevant lawsuits, without examination of concrete cases, which only occurred in 2019, with the trial of Special Electoral Appeal No. 19,392, when the Court recognized gender fraud as a violation of human dignity itself, with the surreptitious conduct of registering women only formally, without giving them any real opportunity for dispute.

In this judgment, the Court recorded that the evidence of fraud should be robust and take into account the sum of the circumstances, specifying which were necessary to elucidate that case, namely:

a) identical records in the accounts of candidates, such as types of expenses, dates and numerical sequence of tax invoices, in true accounting makeup;

b) dispute of the same position with close relatives, without any record of animosity between them, without spending on the woman's propaganda and her ostentatious support to the men of this nucleus;

c) negligible vote.

It happens that, even without proof of the fraud of each person, stating that it would be enough to prove the conduct - without requiring individual participations, specific beneficiaries - for the impeachment of all mandates, including elected women who did not participate in the illegality.

The central argument of this judge, in a game of utilitarian words not to protect the elected, is that as the legal quota is gender, keeping them in office, would violate affirmative action!

At the same time, it refused to hold the representatives of the political parties who took the candidacies to the register, in an endless perplexity, emptying the legal good he claimed to protect.

Decisions such as these, which have been repeated in other Electoral Courts, lead to the revictimization of women and externalize the cruel face of gender political violence mesmerized by the justice system, which 
does not welcome victims of the abuse of patriarchal family power, which eventually reproduce the acts of submission, in a cycle of repetition of violence, as Pierre Bourdieu describes (2012, p. 22).

And so, elected women are turned away by the actions of others, naturalizing male domination, blaming the woman for the conduct of her executioner, in the odious cycle of public erasure.

\section{GENDER POLITICAL VIOLENCE IN COLOMBIA}

Talking about gender-based political violence in Colombia dates back to the internal conflict that has raged for more than six decades and a number of victims totaling 9,068,190 people, of whom 5,627,60 are women and 3,518 are from the LGBTI population ${ }^{13}$. Many of these people do not recognize their own condition, precisely for fear of new victimization ${ }^{14}$.

The history of the Andean country is marked by political conflicts and a prolonged result, as Mendieta and Tobón portray:

The conflict is a constant in the history of Colombia. In the 19th century, there were nine civil wars, but the 20th century was no better. Partisan clashes, the rise of guerrilla warfare, drug trafficking, and paramilitary groups have turned the country into a field of legal and illegal battles, which were faced by the hegemony of a territory that stands out for its wild mountains, leafy jungles, and flowing rivers. (MENDIETA; TOBÓN, 2020, p. 245).

Over the past twenty years, Colombia has made important efforts to recognize the factors that have generated political violence in search of solutions. This is demonstrated in verdict T025, from 2004, of the Constitutional Court, in which the Supreme Court declared the state of affairs unconstitutional in the face of victims of forced disappearance in the country and ordered resolutions to overcome this situation in the face of specific violence committed against women, girls and LGBTQI population.

It is important to mention Processes No. 092, 2008 and No. 009, 2015, which showed how the members of these populations are more at risk of being victimized. Also in this meantime was created Law No. 1448, of 2011, through which measures were adopted for attention, assistance and full reparation of victims of the conflict. Similarly, in 2016, the peace 
agreement between the Colombian State and the FARC guerrilla group was signed, with the central point of recognizing the victims of the conflict, deserving of truth, justice, reparation and guarantee of non-repetition.

Along these lines, in Colombia, there are greater risks of being the victim of armed conflict for gender reasons than for others, as acknowledged by the Constitutional Court, when judging the case presented in Lawsuit No. 092, 2008.

Sexual violence has become a habitual practice that is systematically and invisible in the context of the Colombian armed conflict (Verdict C781, 2012, of the Constitutional Court).

There are many complaints of sexual violence against women, of these, many children and adolescents, recording an almost absolute impunity framework, involving armed actors, surpassing 95\% of the cases of sexual violence reported by the Constitutional Court (according to the Bureau of Monitoring of the Lawsuits No. 092, 2008, and No. 009, 2015).

According to the referred Bureau, the Colombian State, headed by the Fiscalía General de la Nación, in practice renounced its duty to investigate 72.3\% of the cases remitted to the Lawsuit No. 09, 2015.

This process reiterated what had already been observed in Case no. 092, 2008, that is, it verified the continuity of factors that enable sexual violence within the armed conflict in Colombia. In this opportunity, they were classified into contextual and subjective factors.

Contextual factors determine two situations: the presence of armed actors in territories of these populations and the absence or weakness of institutions to sanction these crimes.

Subjective factors may be age, belonging to determined ethnic groups such as indigenous people, African descent, and sexual orientation or gender identity.

Therefore, reasons of gender, ethnicity and sexual orientation continue to be causes of victimization of women in Colombia.

According to the Constitutional Court, violence against them has a different, acute character, because they are more exposed to multiple risks, such as violence by sexual exploitation; slavery for labor exploitation; forced recruitment of them and their children; attacks because they have family or affective relationships with members of 
groups outside the law or public force; derived from being members of human rights defenders groups; because they are social leaders; murder or disappearance of their companions or children with the consequent destruction of the family group.

This framework forces them to start a new life, often far from their places of origin, in precarious conditions, risk of greater discrimination and vulnerability conditioned to assume new social and economic family roles that, in many cases, affect their physical and psychological health (Case No. 092, 2008, Constitutional Court).

Proof that it is possible, when one wants, to act on behalf of women, soon after the peace agreement between the Colombian State and the FARC guerrilla was concluded, the Special Justice Court for Peace (SJCP) was created in 2016, opening a new opportunity to offer justice to so many women and girls.

Until then, these claims had not been heard.

During the two years in which the SJCP operated, at least twenty-one reports of sexual violence were submitted, that should be transmitted to the true recognition room, responsibility and determination of acts and conduct (SRVRDHC). According to the law guiding the procedures of the Special Justice Court for Peace (Law No. 1922, 2018) these offenses are part of several macro-processes opened by the same cour ${ }^{15}$.

It is necessary to evaluate the results of the SJCP, because there is no sentence, but the systematic attacks against this institution and the proposals to eliminate it. These threats harms, even more, millions of women victimized during the armed conflict, also invisible to the justice system

In the face of political violence for gender reasons, new challenges are presented for Colombia, because after the signing of the agreement between the Colombian State and the FARC, the murder of social leaders as presented has increased exponentially: in 2016 there were 21; in 2017 there were 208; 2018 with 298; 2019 with 279 and 2020 with 194 to date. Of these people exterminated, $13.3 \%$ are women.

This picture is worrying because since the peace agreement and until August 21, 2020, more than 1000 social leaders have been murdered and this figure only increases ${ }^{16}$. 
As noted, there is a close relationship between armed internal conflict and violence for ethnic, gender and sexual identity orientation, which records the historical debt to these people.

This scenario reveals the exclusion of fundamental rights, as Mendieta and Tobón state:

From this perspective, the historical, social, economic and political exclusion suffered by some groups, such as women, indigenous peoples, descendants of Africans and the LGTBI community in most Latin American countries, prevents full enjoyment of the exercise of their rights. (2018, p. 287).

All this demonstrates that gender-based violence is embedded in Colombia and is directly reflected in women's political participation.

Put another way, even with the creation of the quota law for women's participation in public life, in numbers slightly higher than those in Brazil, the Colombian Parliament has the representation of only 19.9\% of women, yet the parties, dominated by men, decide whether such lists will be opened or closed.

Colombia adopts bicameralism and the election takes place by proportional representation of lists, but the path to the implementation of electoral quotas has not been easy, as highlighted here and elsewhere (ATENEA, 2019).

\section{ON THE SUBJECT OF FINAL NOTES: INTERNATIONAL DOCUMENTS AND THE BASIS FOR THE CONSTRUCTION OF THE NEW FEMINIST CONSTITUTIONALISM}

It is not new that the processes of historical affirmation of gender equality are linked to the creation of international legal documents to protect human rights.

From the Charter of the United Nations to the Durban Convention (2001) there are more than a dozen documents that reaffirm and require states to proceed substantially in the pursuit of equality between men and women. 
The Convention on women's political rights (UN, 1953) stands out, outline in Articles 2 and 3 that they will be eligible for all public bodies constituted under national legislation, without any restriction, as well as, on an equal footing with men, they will have the same right to occupy public positions and perform public functions established in national law.

In the same sense, gender equality is described as the 5 th objective among the 17 fixed for sustainable development, drafted at the United Nations Conference in Rio de Janeiro, in 2012.

These objectives for sustainable development extend the concept of equal democracy and wave a new model for national States, "in which parity and substantive equality constitute founding elements". Since then, "equal democracy implies profound qualitative and quantitative transformations that include women's political participation to confront various violations of rights against women and girls". (UN, PARLATINO, 2014) (Own translation).

The eradication of structural dysfunctions, such as sexism and racism, is essential to the reorganization of this new State, indene of gender political violence, pointing to the social balance so desired by a fair and democratic society.

Exactly on this path, the Normative Mark for Consolidating Equal Democracy emerges in 2015 as a recommendation to the national parliaments of the Latin American and Caribbean region, pointing out the necessary institutional and political reforms that promote and ensure equality between men and women (UN; PARLATINO, 2014).

Article 13 is highlighted in Normative Mark, which calls on the legislative power to take over gender equality committees and the boost of projects that promote effective compliance with equal democracy.

This regulation provides for the equal representation of the legislative assembly, the presidencies of the internal committees, as well as the formation of intraparty benches, of women.

Given all the effort affirmed by these statements, as well as their affirmation in international jurisdictions through reports, advisory opinions and recommendations, the gulf persists between ratification and its implementation on domestic soil. 
But the international pressure towards this new feminist constitutionalism has given results, although timid, as seen after the recommendation of the Organization of American States, through the request made by the Electoral Observation Mission in the 2018 election, with the creation, in the structure of the Brazilian Superior Electoral Court of the gender policy management committee, responsible for encouraging women's political participation, as well as for expanding the visibility of electoral and statistical data, fostering educational actions and encouraging the development of cooperation networks that promote dialogue on the subject with society and other institutions ${ }^{17}$.

Bringing together the legal statutes of national states, associated with international provisions, it is possible to talk about the perspectives of gender equality, which impose a necessary and urgent challenge for the consolidation of the state that obeys the rule of law in the southern part of Latin America.

To address these perspectives, it implies considering the concerns of all women and men, seeking elaboration, application, supervision and evaluation of economic and social policies, always under the eyes of women, girls and adolescents.

As Marie Cristine Fuchs points out, addressing seminal work on feminist constitutionalism, the implementation of laws and the fulfillment of verdicts must always take place from the gender perspective, to correct distortions (such as that seen in the discourse of application on gender quota fraud by the Brazilian electoral justice). In fact, "feminist constitutionalism becomes an important ally to strengthen the state the obeys the rule of law, having as its purpose to bring the right closer to social reality, bringing together and interacting with the needs of those who make up half of the historically excluded population" (In: SILVA; BARBOZA; FACHIN, 2020, p. 8) (Own translation).

Beautiful to see, the experience of Chile, with the response to the Plebiscite, on October 25, 2020, where feminist movements drove protests that forced the drafting of a new Constitution by a Joint Committee ${ }^{18}$, should be the practice, so that the gender perspectives, towards substantial democracy, sustain overcoming the simulacrum that formal equality portrays. 


\section{Those who live and persist will see a new era.}

\section{NOTES}

1 THE GUARDIAN. Warning over rise in UK domestic abuse cases linked to coronavirus. Available at: https://www.theguardian.com/society/2020/mar/26/warning-over-rise-in-uk-domestic-abuse-cases-linked-to-coronavirus.

2 BRAZILIAN PUBLIC SAFETY YEARBOOK 2020. Domestic and sexual violence. Available at: https:// forumseguranca.org.br/wp-content/uploads/2020/10/anuario-14-2020-v1-interativo.pdf. (Own translation).

3 EL PAÍS. Latin America is the most lethal region for women. Available at: https://brasil.elpais. com/brasil/2018/11/24/actualidad/1543075049_751281.html. (Own translation).

4 Framework based on information obtained in the Registraduría Nacional Del Estado Civil. Available at: https://www.registraduria.gov.co/IMG/pdf/boletin_rnec_-_onum.pdf.

5 Figures extracted from the Superior Electoral Court. Available at: https://www.tse.jus.br/eleicoes/estatisticas/estatisticas-eleitorais.

6 CONGRESS IN FOCUS. 90,000 black women are running in municipal elections, 23\% more than in 2016. Available at: https://congressoemfoco.uol.com.br/eleicoes/90-mil-mulheres-negras-disputam-as-eleicoes-municipais-23-a-mais-que-em-2016/ (Own translation).

7 Available at: https://www.violenciapolitica.org/.

8 Through The declaration of unconstitutionality of the articles of Law 9.096/95, in Direct Action of Unconstitutionality No. 4,650, the decision given on September 17, 2015, published on March 4, 2016.

9 Available at: http://www.stf.jus.br/arquivo/cms/noticiaNoticiaStf/anexo/ADPF738cautelar.pdf.

10 Available at: https://www.tse.jus.br/imprensa/noticias-tse/2020/Novembro/mulheres-representam-apenas-12-dos-prefeitos-eleitos-no-1o-turno-das-eleicoes-2020.

11 According to Brazilian Public Security Yearbook 2020. Available at: https://forumseguranca.org. br/wp-content/uploads/2020/10/anuario-14-2020-v1-interativo.pdf.

12 REDE BRASIL ATUAL. Political violence against women candidates is an 'attack on all women' Available at: https://www.redebrasilatual.com.br/politica/2020/11/manuela-davila-violencia-politica-contra-mulheres/ (Own translation).

13 Data obtained on the victim's attention and repair unit page, consulted on November 14, 2020. Available at: https://www.unidadvictimas.gov.co/es/registro-unico-de-victimas-ruv/37394. (Own translation).

14 Press release of March 29, 2019, on the report on sexual violence against LGBT people by the Colombian and the Caribbean affirmative. Available at: https://www.jep.gov.co/Sala-de-Prensa/ Paginas/ColombiaDiversa-y-Caribe-Afrmativo-entregaron-informes-sobre-violencia-sexual-a-la-JEP.aspx. On the subject is a central reference to the report produced by CNMH (2015) "Annihilate the difference. Lesbians, gays, bisexuals and transgender people in the context of Colombia's armed conflict". See also: BUENO-HANSEN, Pascha, "The Emerging LGBTI Rights Challenge to Transitional Justice in Latin America", at: International Journal of Transitional Justice, 2017, p. 1-20 (Own translation).

15 It is necessary to number macro processes: Caso No. 004 on the "Territorial Situation of Urabá" (knowledge evoked by Case No. 040 of 2018); Case No. 007 on "Recruitment and use of children in armed conflict" (evoked by Case No. 029 of 2019); Case No. 006 on victimizing facts against members of the Patriotic Union (evoked by Case No. 027 of 2019) and Case No. 005 on the "Territorial Situation of the Northern Cauca Region" (evoked by Case No.078 of 2018) (Own translation).

16 Information obtained on the "Indepaz" website. Available at: http://www.indepaz.org.co/1-000-lideres-y-defensores-de-ddhh/. (Own translation).

17 SUPERIOR ELECTORAL COURT OF BRAZIL. The Presidency of the Superior Electoral Court of Brazil establishes a committee on gender policy. Available at: https://www.tse.jus.br/imprensa/ 
noticias-tse/2019/Outubro/presidencia-do-tse-institui-comissao-gestora-de-politica-de-genero. (Own translation).

18 EL PAÍS. A constitution with a gender perspective in Chile. Available at: https://brasil.elpais.com/ internacional/2020-11-03/uma-constituicao-com-perspectiva-de-genero-no-chile.html. (Own translation).

\section{REFERENCES}

ALZIRAS INSTITUTE. Brazilian prefectures and political parties. Available at: https://mulheresnaseleicoes.org.br/relatorio1/. Access on: November 13, 2020 (Own translation).

BEARD, Mary. Mujeres y poder. Barcelona: Editorial Planeta, 2018.

BOURDIEU, Pierre. A dominação masculina. 11ํㅡㄹ ed. Rio de Janeiro: Bertrand Brasil, 2012.

BRAZIL. Brazilian Superior Electoral Court. Consultation 060025218.2018.6.00.0000 (PJe) - BRASÍLIA - FEDERAL DISTRICT. Available at: https://www.conjur.com.br/dl/voto-rosa-weber-consulta-publica.pdf. Access on: November 14, 2020 (Own translation).

BRAZIL. Brazilian Superior Electoral Court. Ordinance No. 791, October 10, 2019. Establishes the Gender Policy Management Committee of the Superior Electoral Court (TSE Women), linked to the Presidency. Available at: https:// www.tse.jus.br/legislacao/compilada/prt/2019/portaria-no-791-de-10-deoutubro-de-2019. Access on: November 14, 2020 (Own translation).

BRAZIL. Brazilian Supreme Court. Direct Action Of Unconstitutionality No. 5617/Df. Available at: https://jurisprudencia.stf.jus.br/pages/search/ sjur391945/false. Access on: November 14, 2020 (Own translation).

BRAZIL. House of Representatives. Draft Bill 349. Discourse about combating violence and political-electoral discrimination against women. Available at: https://www.camara.leg.br/proposicoesWeb/prop_mostrarintegra;jsessioni $\mathrm{d}=$ 24CF6346F7DFC6D2D6AE7C991E0895B2.proposicoesWebExterno1?codt eor $=1300107 \&$ filename $=P L+349 / 2015$. Access on: November 14, 2020 (Own translation). 
BRAZIL. House of Representatives. Draft Bill 5114. It creates mechanisms to curb gender violence and political discrimination against women and provides other measures. Available at: https://www.camara.leg.br/proposicoesWeb/ prop_mostrarintegra?codteor $=1940914 \&$ filename $=P L+5114 / 2020$. Access on: November 18, 2020 (Own translation).

BRAZIL. House of Representatives. Draft Bill 5295. It creates mechanisms to combat harassment and political violence against women candidates and in the exercise of public life. Available at: https://www.camara.leg.br/proposicoesWeb/ prop_mostrarintegra? codteor $=1944538 \&$ filename $=P L+5295 / 2020$. Access on: November 30, 2020 (Own translation).

BRAZIL. House of Representatives. Draft Bill No. 4963. Establishes rules to prevent, sanction and combat political violence against women or on grounds of gender. Available at: https://www.camara.leg.br/proposicoesWeb/fichadetrami tacao?idProposicao=2250640 Access on: November 14, 2020 (Own translation).

BRAZIL. House of Representatives. Women's Charter to Constituents. Available at: https://www2.camara.leg.br/atividade-legislativa/legislacao/ Constituicoes_Brasileiras/constituicao-cidada/a-constituinte-e-as-mulheres/ arquivos/Constituinte\%201987-1988-Carta\%20das\%20Mulheres\%20aos\%20 Constituintes.pdf. Access on: November 14, 2020 (Own translation).

BRAZIL. House of Representatives. Women's Charter to Constituents. Available at: https://www2.camara.leg.br/atividade-legislativa/legislacao/ Constituicoes_Brasileiras/constituicao-cidada/a-constituinte-e-as-mulheres/ arquivos/Constituinte\%201987-1988-Carta\%20das\%20Mulheres\%20aos\%20 Constituintes.pdf. Access on: November 13, 2020 (Own translation).

BRAZIL. Law No. 9504 of September 30, 1997. Available at: http://www. planalto.gov.br/ccivil_03/leis/L9504compilado.htm. Access on: November 15, 2020 (Own translation).

BRAZIL. Sustainable Development Goals. Available at: https://odsbrasil.gov. br/objetivo/objetivo?n=5. Access on: November 14, 2020 (Own translation).

COELHO, Margarete de Castro. 0 teto de cristal da democracia brasileira: abuso de poder nas eleições e violência política contra as mulheres. Belo Horizonte: Fórum, 2020. 
COLOMBIA. Colombia Diverse and Affirmative Caribbean. Available at: https://www.jep.gov.co/Sala-de-Prensa/Paginas/ColombiaDiversa-y-CaribeAfrmativoentregaron-informes-sobre-violencia-sexual-a-la-JEP.aspx. Access on: November 14, 2020 (Own translation).

COLOMBIA. Follow-Up Table of the Lawsuits No. 092 of 2008 And No. 009 of 2015: Impunity of sexual violence associated with armed conflict in Colombia. Available at: https://www.colectivodeabogados.org/IMG/pdf/la_impunidad_ de_la_violencia_sexual.pdf. Access on: November 14, 2020 (Own translation).

COLOMBIA. Unit for Victim Care and Repair. Available at: https://www. unidadvictimas.gov.co/es/registro-unico-de-victimas-ruv/37394. Access on: November 14, 2020

EMCKE, Carolin. Contra o ódio. Belo Horizonte: Editora Âyiné, 2020.

FARRIS, Sara R. Femonazionalismo: il razzismo nel nome dele donne. Roma: Editora Alegre, 2020.

FERREIRA, Paula Camila Veiga. Autoafirmação das mulheres: perspectivas para transposição das invisibilidades organizacionais por meio de uma teoria política de justiça substancialmente igualitária. Belo Horizonte: Editora Conhecimento, 2020.

GRUBER, Lilli. Basta! Il potere dele donne contro la politica del testosterone. Milano: Media Group, 2019.

HOOKS, Hell. Anseios: raça, gênero e políticas culturais. São Paulo: Editora Elefante, 2019.

INSTITUTE OF STUDIES FOR DEVELOPMENT AND PEACE (INDEPAZ). Available at: http://www.indepaz.org.co/1-000-lideres-y-defensores-de-ddhh/. Access on: November 14, 2020 (Own translation).

LAS HERAS, Néstor Orejón Sanchéz. La circunstancia agravante genérica de discriminación por razones de género. Madrid: Iustel, 2019.

LÔBO, Edilene. Processo Eleitoral Democrático e as Ondas de Direitos Políticos das Mulheres. Revista de Teorias da Democracia e Direitos Políticos. Salvador, v. 4, n. 1, Jan./Jun. 2018, p. 95-114. 
MACCAN, Hannah. 0 livro do feminismo: as grandes ideias de todos os tempos. Rio de Janeiro: 2019.

MELLO, Patrícia Campos. A máquina do ódio: notas de uma repórtes sobre fake news e violência digital. 1ํㅡㄹ. ed. São Paulo: Companhia das Letras, 2020.

MENDIETA, David; TOBÓN-TOBÓN, M. L. (2018). La dignidad humana y el Estado Social y Democrático de Derecho: el caso colombiano. Revista de Estudos Constitucionais, Hermenêutica e Teoria do Direito (RECHTD), 10 (3), p. 278-289.

MENDIETA, David; TOBÓN-TOBÓN, M. L. (2020). La pequeña dictadura de la COVID-19 en Colombia: uso y abuso de normas ordinarias y excepcionales para enfrentar la pandemia. Opinión Jurídica, 19(40), p. 243-258.

SILVA, Cristine Oliveira Peter da; BARBOZA, Estefânia Maria de Queiroz; FACHIN, Melina Girardi. Constitucionalismo feminista. Salvador: JvsPodium, 2020.

UN WOMEN. ATENEA - Mechanism to accelerate women's political participation in Latin America and the Caribbean. Available at: http://www. onumulheres.org.br/wp-content/uploads/2020/09/ATENEA_Brasil_FINAL.pdf. Access on: November 14, 2020 (Own translation).

UN WOMEN. ATENEA. Colombia: Time for parity. Available at: https://colombia. unwomen.org/es/biblioteca/publicaciones/2019/09/ateneacolombia. Access on: November 14, 2020.

UN WOMEN. Normative Mark to consolidate peer democracy. Available at: http://www.onumulheres.org.br/wp-content/uploads/2018/06/MarcoNormativo-Democracia-Paritaria_FINAL.pdf. Access on: November 14, 2020 (Own translation).

UNITED NATIONS. Charter of the United Nations. Available at: https://www. un.org/en/charter-united-nations/index.html. Access on: November 12, 2020.

UNITED NATIONS. Convention on the political rights of women. Available at: https://treaties.un.org/pages/ViewDetails.aspx?src=TREATY\&mtdsg_no=XVI1\&chapter=16\&lang=en. Access on: November 12, 2020. 
VENTURI, Gustavo; BOKANYL, Vilma (Orgs.). Diversidade sexual e homofobia no Brasil. São Paulo: Editora Fundação Perseu Abramo, 2011..

Artigo recebido em: 03-12-2020

Autores convidados

\section{Edilene Lôbo}

PhD in Law from the Pontifical Catholic University of Minas Gerais. Master's degree in Law from the Federal University of Minas Gerais. Professor of the Master's and Doctorate Program in Law at the University of Itaúna. Lawyer. Email: edilenelobo@yahoo.com.br.

\section{David Mendieta}

$\mathrm{PhD}$ in Law from the Complutense University of Madrid. Master's degree in Law from the University of Antioquia-Colombia. Coordinator of the Doctorate in Law of the University of Medellín. Lawyer. Email: dmendieta@udem.edu.co.

\section{Daiane Moura de Aguiar}

$\mathrm{PhD}$ and Master in Law from the University of Rio dos Sinos. Professor at the School of Law and the School of Business of Anhembi Morumbi University. Lawyer. Email: daianemouradeaguiar@gmail.com

Universidade de Itaúna, Facudade de Direito.ROD MG 431 - KM 435. Trevo de Pará de Minas. 35680142 - Itaúna, MG - Brasil - Caixa-postal: 100 
